Portland State University

PDXScholar

\title{
Unipolarity and Foreign Policy: an Examination of the Unipolar U.S and Its Subsequent Foreign Policy Constraints
}

Madeleine Smith

Portland State University

Follow this and additional works at: https://pdxscholar.library.pdx.edu/honorstheses

Part of the International Relations Commons

Let us know how access to this document benefits you.

\section{Recommended Citation}

Smith, Madeleine, "Unipolarity and Foreign Policy: an Examination of the Unipolar U.S and Its Subsequent Foreign Policy Constraints" (2020). University Honors Theses. Paper 835.

https://doi.org/10.15760/honors.854

This Thesis is brought to you for free and open access. It has been accepted for inclusion in University Honors Theses by an authorized administrator of PDXScholar. Please contact us if we can make this document more accessible: pdxscholar@pdx.edu. 


\section{Unipolarity and Foreign Policy:}

\section{An Examination Of The Unipolar U.S And Its Subsequent Foreign Policy Constraints Maddie Smith}

The modern world has been characterized by the structure of U.S unipolarity within the international system for almost 30 years now. Many scholars like Kenneth Waltz saw this as a fleeting moment that was sure to fall prey to counterbalancing and would never last. However, since the fall of the Soviet Union, the international system indeed has remained unipolar, with the U.S as the unipole. During the era of the Cold War, neorealists often characterized the structure of bipolarity as the most stable and the one that would prevent great power conflict. However, as we have transitioned out of that system into our modern day circumstances, with the U.S at the lead, this makes the question of what comes next particularly intriguing. As history has shown, no polarity balance, whether bi, multi, or uni polarity has lasted forever. But this has been the first case in which unipolarity has existed in a time characterized by modern nuances such as nuclear warfare, non-state actors, and the modern nation-state balance.

Great power conflict is something that has more dire consequences now than it perhaps did in the $19^{\text {th }}$ and $20^{\text {th }}$ centuries. As such, the transition from being on top to perhaps once again in a power competition with other nations is a coming reality fraught with uncertainty, especially in the foreign policy community. The result of the unipolar moment has been the U.S's 
capitalization on being the unipole and subsequently the international system has been structured according to how we saw fit. Our foreign policy has also reflected the constraints and benefits of being the unipole for over two decades now. The U.S has almost in a way structured its ultimate grand strategy goals around maintaining this structure of unipolarity, despite that actually being out of any one state's control.

Despite the surface level benefits that may be potentially reaped from the U.S's status as the unipole, it is now increasingly predicted that a coming polarity shift is imminent in the form of a rising China. Since the early 80 's China's GDP has risen at a rate of almost $10 \%$ per year following the series of economic reforms. As the country has continued to rival the U.S economic strength and even surpass it in 2014 in purchasing power according to data found from the IMF World Economic Outlook database, scholars are quick to note that this trend is one of the major ways in which neorealists tend to gauge power. In neorealist conceptions of what it means to be a "superpower" vs. a "great power", generally it is accepted that countries with strong economies, substantial land space, large populations, and regional power are the foundational steps often need to transition from a "great power" to a "superpower". Of course as is also neorealist tradition, there is no hard and fast rule to exactly what makes a "superpower" or "great power", or what the magic formula may be to transition from one or the other; but as China continues to grow in the foundational areas of typical power components, it is easy to see why this is causing the world some unease.

Before one can discuss the potential polarity shifts, it is important to establish that the world is in fact unipolar at this moment in time and has been since about the fall of the Soviet Union, if not perhaps slightly before as well. According to William Wohlforth's 1999 article "The Stability of a Unipolar World" the United States “ enjoys a much larger margin of 
superiority over the next most powerful state or, indeed, all other great powers combined than any leading state in the last two centuries. Moreover, the United States is the first leading state in modern international history with decisive preponderance in all the underlying components of power: economic, military, technological, and geopolitical. To describe this unprecedented quantitative and qualitative concentration of power as an evanescent "moment" is profoundly mistaken" (Wohlforth, 1999). Since this article was published, this observation has remained over the last two decades, but scholars still disagreed over whether or not this observation was true and the system was truly unipolar. For the purposes of this paper, however, I will be agreeing with Wohlforth and other scholars' assessment of current unipolarity with the United States as the only superpower within the system.

The current unipolar system for the purposes of this paper is undeniable, but also undeniably going to shift in the future. Yet as unipolarity has persisted, the U.S has made many foreign policy and grand strategy decisions based on the structural constraints and flexibilities of being the unipole. This trend may not be an advisable one should a shift in power occur. My question is, should the system return to bi or multipolarity, how will U.S foreign policy be able to accommodate these changes peacefully after it has so long been centered around maintaining the unipolar system and its current status? Additionally how will the U.S negotiate other rising powers, once they do rise enough to present real challenges to the status quo? Essentially seeing as China is the clear candidate for being the fastest rising power, how will the U.S navigate its relationship to avoid returning to an era reminiscent of Cold War tensions. The aim of this thesis is to do a literature review from the book "International Relations and the Consequences of Unipolarity" to help bring light to these questions. 


\section{A Structure Analysis}

In Jervis's article, he starts by discussing some key questions that scholars must ask themselves for a structural analysis of the unipolar system and its definition. It is well known that the unipole does not have control over outcomes, but Jervis says a good litmus test to explore this relationship between capabilities and power is to actually look at how often the unipole actually gets what it wants. This is to help address the two different definitions of the unipolar system; one marked by just capabilities and the other defined by total security for the unipole. Both are linked by the underlying assumption that the privileged position of the unipole leads to security. This is a difficult assumption to verify seeing that capabilities and power are not entirely straightforward and even despite a state having sufficient capabilities and power, this may not entirely enable the state to reach all of their objectives, should their values or behavior be found unacceptable by the international community.

Essentially Jervis argues that unipolar systems hinge largely on what unipoles desire as they grow and the desires depend largely on the specific idiosyncrasies of whichever superpower. Unipolar systems thus are nonidentical. As Jervis explains for the implications of the specific unipole characteristic on its control over objectives, "Whether others will comply also depends on nonstructural factors, especially the coincidence of discrepancy between the worlds they prefer and the one sought by the superpower. Of course the actors' preferences may themselves be subject to influence, and we would expect the unipole to make serious efforts to persuade or coerce...the others to develop goals, values, and beliefs that are compatible with its own. Indeed inducing such a consciousness...is over the long run the cheapest and most secure form of influence. Whether these efforts will succeed depends in large part on how compatible 
the unipole's objectives are with those of the others and the skill with which it acts" (Jervis, pg. 257).

This observation also leads to the related question of which threats actually challenge the security of a unipole. Jervis points out that traditional theories tie the longevity of the unipole to the economy, due to the fact that a strong economy is needed to protect the cost of its position. Yet he notes should the unipole be able to profit off its position, the unipolar structure is largely self-sustaining. While this observation is not enough to protect the unipole completely from instability (it does not protect the unipole from economic shocks) it does however represent a bigger break from past systems by "take[ing] states out of anarchy and transforms if not dissolves international politics in two related ways. First security concerns are greatly reduced for the unipole and others it protects....second some of the relations under unipolarity will embody a degree of hierarchy...the unipole cannot dictate but it can set at least some of the rules and can enforce agreements among others (although it itself cannot be bound)" (Jervis, pg. 258259).

Essentially, the result from the years under unipolarity has been a shift from past unipolar systems like those of ancient Rome or China, to one where the U.S is calling the shots and organizing the international system. Unlike past unipolar systems, the current one is characterized by modern developments like nuclear weapons, liberal values and more of a "security community" stemming from the high cost of modern war. It is also largely defined by the characteristics of the U.S itself in values, politics, and outlook. According to Jervis structuralist claims analyzing the system say any unipole would behave as the U.S has due to the constraints inherent in the system. But as Jervis has already mentioned, to expect unipolarity to look the same under different regimes like the USSR or China is to ignore the fact that it is 
extremely difficult to separate the impact of the "soft power" influences exported by the unipole. America's insistence on democracy or liberal values does not reflect prudent statecraft in response to structure, but indeed reflects how under unipolarity the internal factors like regime and individual president attitudes may matter more than external factors.

Jervis discusses this by analyzing the Iraq war and the idea that has somewhat dictated American foreign policy, which is the attitude of to "be complacent is to allow alternative powers to rise" (Jervis, 272). The most extreme example of this attitude is the Iraq war in which the U.S and its allies felt it was best to take preventative steps in the form of war. This type foreign policy driven by American values like democracy promotion, has continued to steer the direction of foreign policy well past its initiation in President Bush's term. The intensity has lessened as Jervis notes, but even under the Obama administration more troops were still sent to Afghanistan with the goal of democratization in the region. As Jervis best explains, "the current lack of a superpower competitor has not made the U.S comfortable with other kinds of regimes" (Jervis, 272). The structure of unipolarity has made the U.S brand of unipole power almost desirable to other countries despite any overreach in its foreign policy. It has also created a deeply mistrustful U.S that is uninterested in anything other than perpetuating the current status quo.

The regimes of the Middle East did not present any real threat like that of China, but they were still enough to encourage policies that at their heart wanted to keep the influx of American power stable. Yet even with the perhaps irrational and ambitious self interested foreign policy that came out of the Bush era, no legitimate balancing coalitions have formed against the U.S. As I had previously mentioned, instead of leading powers acting in ways balance of power theory would predict to unite against American unipolar power, they have formed a "security 
community" as Jervis coins it. Indeed while Jervis also points out the fact that neither China nor Russia are a part of this security community, neither country has attempted to unite in order to balance against the unipole either-contrary to what balance of power theorists would predict.

Jervis attributes this trend to the oversight balance of power theory does not account for which is, what happens once the unipole is already established. The theory makes predictions that states will form coalitions in order to help prevent a hegemon from completing it's full rise, but it doesn't convincingly speak of what happens after unipolarity is already in effect. "What is equally crucial is that balance of power dynamics arise in the context of the use, threat, and fear of force. But as we have seen, the leading powers now form a security community. The incentives to try to overturn unipolarity are much less when states do not fear that the superpower will invade them or greatly diminish their sovereignty. Indeed, if they believe that the unipole will provide a degree of order and public goods and that rivalry would be destabilizing, they may actively support unipolarity. While self-interest may underlie the Bush administration's argument that the rise of any other country or group of countries to challenge the US would lead to conflict if it failed and to instability if it succeeded, the claim may be correct and/or may be seen as such by many other countries. The record of bipolarity and multipolarity is not attractive...cautious men and women might not opt to run the experiment" (Jervis, 275).

\section{Legitimacy and Hypocrisy Under Unipolarity}

The U.S has made foreign policy decisions based on the structure of unipolarity and the certain ways the structure of the system has caused the U.S to react in response. One way in which unipolarity has helped dictate certain decisions, stems from the role legitimacy and hypocrisy play in a unipolar system as Finnemore discusses in her article. Often overlooked by 
the more material aspects of a unipole's power such as military capabilities or economic strength, Finnemore explains how, "material force alone remains to impose order, and order creation or maintenance by that means is difficult, even under unipolarity. Successful and stable orders require the grease of some legitimation structure to persist and prosper...unipoles attempt to articulate some set of values and shared interests that induce acquiescence or support from others, thereby legitimating their power and policies...acceptance by or overt support from others makes exercise of power by the unipole cheaper and more effective" (Finnemore, 72).

Since the U.S rise to preponderance after the collapse of the Soviet Union, this notion of a need for legitimacy and the pushing of shared values, has been a core component of the U.S brand of foreign policy and international conduct. By pushing values like open markets, the U.S was able to develop "public goods" such as international economic institutions, like the IMF, which in turn are key players in the U.S grand strategy of institutionalizing it's power. As Finnemore notes, it is no coincidence that "current systemic rules demand open markets and free trade" (80) and this norm in turn reciprocally benefits the U.S economy. International authority has essentially resulted from the U.S transformation of its power into these institutions, simultaneously legitimizing the United States and most of its objectives in one fell swoop.

The U.S is a strong unipole due to the way it has positioned itself into championing universal values, despite the ultimate hypocrisy that does follow this sort of rule setting. Great power requires this sort of great legitimacy, and the U.S was able to create its current standing due not only to its rise to the unipole status, but also due to the efforts stemming from the Cold War values promotion in its sphere of influence. "The U.S was a vocal (if not always consistent) proponent of freedom, democracy, and human rights. It built and extended institutional architecture designed to shape global politics in ways that both served its interest and propagated 
its values. So successful was the U.S at legitimating and institutionalizing its power that, by the time the Berlin Wall fell, other models of political and economic organization had largely disappeared. The U.S-favored liberal model of free markets and democracy became the model choice for states around the world not through overt U.S coercion, but in significant part because states had accepted it as the best (ergo most legitimate) way to run a country" (Finnmore, 97).

This observation from Finnemore about not only the importance legitimacy has for the achievement of power, but also the groundwork that was laid prior to the U.S's rise is key to helping look at the question of returning to an era of bipolarity with China. Currently the legitimacy is centered most predominantly on the U.S as is to be expected from the result of the system structuring. But should bipolarity reemerge, it would not be unthinkable to expect the same sort of ploys from China that the U.S executed during the Cold War. However, a key difference I think from the Cold War era, to modern day would be the fact that authority and legitimacy of the current U.S led system have already been accepted by many states. China's main hurdle would be to present a viable alternative to what is already in place and accepted by the current international community.

Thus should we return to a bipolar system, U.S foreign policy would be largely dictated to the upkeep of its unipolar legitimacy and the institutions that cemented its power. It should be noted however, that this current undermining of U.S legitimacy has already begun in several small steps from China, most notably AIIB. As unipolarity becomes more costly and demanding, we should expect more viable Chinese alternatives to U.S led institutions to become a reality. Yet the question of how the U.S and indeed the rest of the world will react, as the shattering of stable authority occurs from these alternatives, remains to be seen. 
The AIIB, otherwise known as the Asian Investment Infrastructure Bank, is China's answer to the IMF and is the result of China's dynamic economic growth that occurred over the last decade. This development coupled with another Chinese initiative called the Belt and Road initiative is indicative of China's first concrete steps towards potentially building foundations for spheres of influence with neighboring countries in Asia. The initiatives were originally met with concern from the American side, and there was an effort from U.S politicians to dissuade allies like South Korea, Australia, and the United Kingdom from joining the AIIB. Yet even despite the U.S efforts, these countries did end up joining the AIIB anyways. These developments obviously could pose a real challenge to U.S influence and investment in Asia, due to the fact that the U.S also has vested trade agreements in the region through the Trans-Pacific Partnership (TPP). However, as David Dollar points out in his article, these sort of developments should not be interpreted as a signal of real power or challenge as of yet due to the nature of the Chinese initiatives being more of the

“'hardware' of trade and investment, necessary but not sufficient to deepen integration. TPP, on the other hand, represents the 'software' of integration, reducing trade barriers, opening up services for trade and investment, and harmonizing various regulatory barriers to trade. There is a risk that the competing initiatives of China and the United States will lead to regional blocs and a disintegration of trade, but it is more likely that Sino-American competition will lead to strengthened institutions and deeper integration throughout Asia-Pacific" (Dollar, 2015). There is sympathy for China as an alternative institution builder in the region however, as Dollar already points out the U.S should be more inclined to see the AIIB as a complement to the current American led system more than anything else. 


\section{Unipolarity and Competition}

Perhaps the most pressing issue for this question of unipolar U.S foreign policy adjusting to a bipolar system in the future, is the looming question of how do we prevent great power war or even conflict during the transition. Wohlforth's article addresses this topic by discussing the role status, competition has to play in conflict in addition to discussing how dissatisfaction with the status quo may be affected by different levels of material capabilities. Looking into the theories of war, this will help illuminate the question of what may actually lead to war in the current age of nuclear deterrence and increased costs for the price of great power conflict.

The first question Wohlforth discusses in his article is what makes a rising state begin to challenge the status quo, or even be dissatisfied with it to begin with. He notes how historically and indeed even now, challenger states seemed to thrive and prosper under the very status quos they rose to challenge. China's economy is almost the strongest and the world, and in the international system it is a major player in all decisions and major institutions and their councils. What would cause China dissatisfaction that pushes it to mount a really challenge to U.S led unipolarity? Wohlforth discusses the role perception and status has to do with state dissatisfaction and mentions how often the importance of "a place in the sun" for states such as China really does impact decisions around war and statecraft. "In each paradigmatic case of hegemonic war, the claims of the rising power are hard to reduce to instrumental adjustment of the status quo...Thucydides' account tells us that the rise of Athens posed unacceptable threats not the security or welfare of Sparta but rather to its identity as leader of the Greek world, which was an important cause of the Spartan assembly's vote for war...in post Westphalian Europe, the rising challenger's dissatisfaction is often difficult to connect to the material costs and benefits of 
the status quo, and much contemporary evidence revolves around issues of recognition and status" (Wohlforth, 37).

This aspect of hegemonic wars is alarmingly overlooked in the traditional theories around rising states and causes of war. However, it may have even more of a place in today's era, where the extreme stratification of states due to the structure of unipolarity, causes inherent hierarchy for the international community. The U.S is undeniably at the top for better or for worse and due to its position, its high status is guaranteed. Yet unlike bipolarity or multipolarity, the incentives for states to compete for elevation of their status is somewhat moot. It is costly to challenge the superpower and thus the incentives for direct competition are especially weak. However, as U.S power continues to weaken and the international hierarchy becomes more ambiguous, this is where Wohforth argues great war could occur over positional competition. "“'Dissatisfaction arises not from dominance itself but from a dominance that appears to rest on ambiguous foundations. Thus, status competition is unlikely in cases of clear hierarchies in which the relevant comparison out-groups for each actor are unambiguously dominant materially. Applied to international politics, this begins to suggest conditions conducive to status competition. For conflict to occur, one state must select another state as a relevant comparison that leaves it dissatisfied with its status; it must then choose an identity-maintenance strategy in response that brings it into conflict with another state that is also willing to fight for its position" (Wohlforth, 45).

Status competition and the need to fight over positional status in an unambiguous unipolar system for other states does not exist. However, what should be of great concern to policy makers should the U.S find itself slipping back towards a situation of bipolar competition with China is that observation from Wohlforth. As U.S power becomes less concrete and finds 
itself becoming similar to China in capabilities, the chance of China assessing the U.S as a comparatively similar state may occur. In turn China may begin looking to overtake it positionally due to an increased desire for status, such as the case of Sparta and Athens. The U.S of course would then be forced to perform the aforementioned identity-maintenance strategy Wohlforth mentions, seeing as it is coming from a place of high status for so long, and will be willing to fight China over something so seemingly artificial as position. This state psychology should not be underestimated, and especially as scholars make calls for the U.S to accept a return to multipolarity, it should be kept in mind the impact a return to these different systems will have on positional competition and status for states. The triggers for great power war will not be so removed as the once were under the current unipolarity.

Additionally it should be noted that China has constantly also favored a narrative of flat hierarchy over single state dominance for many years now. Despite the fact that as Wohlforth has established, a more stratified hierarchical system is helping to keep the need for great competition and conflict over status at bay, China continues to be driven by a desire for great power status after it's "century of shame". This notion of what is driving China's desire to rise has been long discussed by Western scholars. As Wohlforth mentions, "[China's] preference for multipolarity and periodic resentment at what it sees as the United States' assertion of special rights and privileges is also well established. Chinese analyses of multipolarity explicitly reflect the predicted preference for a flat hierarchy over one in what a single state has primacy... while many Chinese have convinced themselves that U.S power predominance cannot last, they do grudgingly acknowledge the world's current unipolar nature... as a result Beijing adopted a 'peaceful' rise strategy that downplays the prospect of direct competition for global parity with the United States" (Wohlforth, 64). 
Wohlforth's analysis of the role of status pursuit provides a more bleak outlook on a coming shift back to bipolarity. Scholars like Jacek Kugler and Douglas Lemke would argue that a satisfied state which catches up with the dominant state through a power transition, should not be a cause of war. Given that today's rising powers have little material dissatisfaction leads to scholars agreeing with this sort of analysis and being overly optimistic about rising peer competitors. However, these sorts of hypotheses lull scholars and foreign policy analysts into a false sense of security. Unipolarity affords the U.S a great many leniencies in its foreign policy and privileges in it's status that would not be afforded to it once it is no longer the unipole. As Wohlforth points out it is much harder to manage status competition than any of the material factors. "While diplomatic efforts to manage status competition seem easy under unipolarity, theory and evidence suggest that it could present much greater challenges as the system moves back to bipolarity or multipolarity. When status is seen as a positional good, efforts to craft negotiated bargains about status contests face long odds. And this positionality problem is particularly acute concerning the very issue unipolarity solves: primacy... With two or more possible claimants to primacy, positional competition and the potential for major power war could once again for the backdrop of world politics" (Wohlforth, 66).

While China claims a peaceful rise strategy and indeed may be very well intentioned in its attempts to carry out that promise, the effect of status competition may be an unavoidable part of the transition back to bipolarity. Thus in order to avoid returning to a Cold War tensions era, U.S and Chinese foreign policy makers alike will need to recognize this issue not only to avoid escalated tensions, but indeed even war. Unlike the material capabilities Thucydides trap that played out between the U.S and Soviet Union, the onus to avoid a similar fate with competition is rapidly approaching the U.S and China. However the current trend of strongmen politics on 
the part of both countries recently makes the expectation for being able to manage the importance of status for both countries even lower.

\section{Transition In Sight}

Given that the works written by these authors were published almost a decade ago, it is important to note how these articles have changed since 2011. As Barry Posen was writing his article, unipolarity was just starting to wane. It is important to keep in mind the context these articles were written in, because they offer some interesting hypotheses that we can already see beginning to unfold, almost ten years after they were made. As Posen argues in his article discussing the coming transition to bipolarity or multipolarity, he mentions several different countries that are candidates for leading this transition. Most obvious is China, but he also mentions the growing power of India and Brazil. Currently it's hard to say whether these other two countries are still clearly in the running for the transition to multipolarity, but it's safe to say that China has acted in much of the ways scholars like Posen predicted, and has started to take the full form of a counter challenger to the U.S.

As China continues to rise, Posen gives an interesting analysis on the way capabilities are analyzed by realists. He gives the example of the Soviet Union and the U.S during the Cold War and the disparity between their two economic capabilities. He notes how, "The Soviet Union was only barely in the US league for most of the Cold War in terms of economic capacity but we think of the era as a bipolar order, in part because the gap between the Soviet Union and the third ranking power in the immediate aftermath of World War Two was so great...Latent Soviet power did exceed that of any actor other than the US...but was barely competitive with the US" (Posen, 321). 
Latent U.S power still trumps many of the other countries at the moment, but to underestimate the weight of China's economic power is a mistake in a capabilities analysis of the two powers. Scholars like Wohlforth have argued that unipolarity is defined by a state who is in "a class by itself" but as Posen points out, that definition can be rather difficult to fulfill. Usually the ability to be in a class by itself is defined by the lack of counter coalitions against the state in question, but again as Posen mentions is the a lack of ability due to arithmetic factors or political factors. This analysis shows that the line between unipolarity and bipolarity is a bit more blurry, and the major economic trends show an increasingly different future. However, it should be noted that even as Posen was predicting the transition to bipolarity he accepted the fact that unipolarity was still in effect writing, ““'The US still enjoys a very comfortable margin of superiority in both extant military power, and the economic underpinnings that make those capabilities possible. Additionally, the US has the global diplomatic and military presences, and the diplomatic and military skills necessary to manage and sustain a truly global foreign policy, if not always successfully. No other nation-state can do so at this time" (Posen, 325).

Posen notes how unipolarity was still intact at the time of this article, and most of what he observed back in 2011 is still true today. China has been growing its influence and diplomatic pull, but it has nowhere near the global reach militarily or diplomatically that the US possesses. What should be noted about his observations however, is that fact that instead of hypothesizing China as the sole competitor to the U.S, Posen offers a different theory where China forms a coalition with another strong power to effectively overcome the U.S in combined capabilities and reach. This hypothesis is an important one especially when looking at it from the angle of directing U.S foreign policy in the future. 
Yes it is a possibility that China could rise as a sole competitor to U.S hegemony, but as of now it also realistic that China courts and ally of consequential power to rise alongside it as well such as Russia, India, or the EU. In response the U.S may "“"vigorously [alter] its own alliance relationships....at the same time these partners may also have other alliance options. A strong incentive to compete for allies would be a mark of a multipolar system, even if the US were still the number one power by a significant margin" (Posen, 327). This potential reality highlights even further that unipolarity is on the wane, but not necessarily US power. The predicted reality of a sole China competition has eclipsed this other foreign policy possibility that the rise of China may cause the U.S to prepare for, especially in terms of changing alliance structures in the coming years. Especially after the Trump presidency, it will be a key time to revisit the current allies of the US and renew their trust in our partnerships. Should the partnerships continue to be alienated as they have been in recent years, it is not a stretch to imagine a situation in which competition for allies does begin.

\section{Conclusion}

As we continue to move towards a future where U.S preponderance is less stable, it will continue to be important for scholars and policy makers to keep the ideas discussed in this paper in mind. The goal of this paper is to help show the coming hurdles US foreign policy is going to need to adapt to in the future, as well as discuss the coming tensions that may arise from shifts in status and alliances. The US has grown complacent in its position over the last twenty years. The system structured as it saw fit, will see disruption as rising powers or coalitions start to make real 
efforts towards either counterbalancing against the US or seeking to take its as the sole superpower in the system.

At the current moment, as previously discussed, I would not say unipolarity is completely over. We have one strong power in the form of China who will present a challenge to the U.S in the coming years and will soon surpass the U.S economically. But the U.S still maintains a military and diplomatic geopolitical hold on more of the world than does China or any other rising power. Whether or not we will return to an era of Cold War tensions or even enter a hot war in the future as perhaps a struggle ensues for security and status is currently unknown and hard to predict. This is the issue the U.S is positioned best to help prevent however, if it can recognize the coming obstacles. Creating foreign policy now that will be better suited to a different power balance in the future will help ensure that the world does not return to an era of intense militarized bipolar tensions. Instead by recognizing the position and power of rising powers, the U.S will be better equipped to adjust its grand strategy goals and readjust the sails as needed when the international system shifts once again. 


\section{References}

Allison, G. (2017). China vs. America: Managing the Next Clash of Civilizations. Foreign Affairs, 96(5), 80-89.

Brands, H. (2017). The Unexceptional Superpower: American Grand Strategy in the Age of Trump. Survival, 59(6), 7-40.

Brooks, S., \& Wohlforth, W. (2015). The Rise and Fall of the Great Powers in the Twenty-first Century: China's Rise and the Fate of America's Global Position. International Security, 40(3), 7-53.

Buzan, B. (2010). China in International Society: Is 'Peaceful Rise' Possible? Chinese Journal Of International Politics, 3(1), 5-36.

Dollar, D. (2017, September 7). The AIIB and the 'One Belt, One Road'. Retrieved from https://www.brookings.edu/opinions/the-aiib-and-the-one-belt-one-road/

Ikenberry, G., Mastanduno, Michael, \& Wohlforth, William C. (2011). International Relations Theory and the Consequences of Unipolarity. Cambridge: Cambridge University Press.

Kapstein, E., \& Mastanduno, Michael. (1999). Unipolar politics : Realism and state strategies after the Cold War. New York: Columbia University Press.

Layne, C. (2006). The Unipolar Illusion Revisited: The Coming End of the United States' Unipolar Moment. International Security, 31(2), 7-41.

Monteiro, N. (2012). Unrest Assured: Why Unipolarity Is Not Peaceful. International Security, $36(3), 9-40$.

Schweller, R., \& Pu, X. (2011). After Unipolarity China's Visions of International Order in an Era of US Decline. International Security, 36(1), 41.

Snyder, G. (2002). Mearsheimer's world--Offensive realism and the struggle for security. International Security, 27(1), 149-173.

Stokes, D. (2018). Trump, American hegemony and the future of the liberal international order. International Affairs, 94(1), 133-150.

Porter, P. (2018). Why America's Grand Strategy Has Not Changed: Power, Habit, and the U.S. Foreign Policy Establishment. International Security, 42(4), 9-46.

Wohlforth, W. (1999). The Stability of a Unipolar World. International Security, 24(1), 5-41.

Zhang, B. (2015). Chinese Perceptions of US Return to Southeast Asia and the Prospect of China's Peaceful Rise. Journal of Contemporary China, 24(91), 176-195. 